\title{
Reading American Fat in France : Obesity and Food Culture
}

\author{
Laura Knowlton - Le Roux
}

\section{(2) OpenEdition \\ Journals}

Electronic version

URL: https://journals.openedition.org/ejas/1363

DOI: $10.4000 /$ ejas. 1363

ISSN: 1991-9336

Publisher

European Association for American Studies

\section{Electronic reference}

Laura Knowlton - Le Roux, "Reading American Fat in France : Obesity and Food Culture", European journal of American studies [Online], 2-2 | 2007, document 2, Online since 05 November 2007,

connection on 08 July 2021. URL: http://journals.openedition.org/ejas/1363 ; DOI: https://doi.org/

10.4000/ejas. 1363

This text was automatically generated on 8 July 2021.

Creative Commons License 


\title{
Reading American Fat in France : Obesity and Food Culture
}

\author{
Laura Knowlton - Le Roux
}

One of the least flattering images that America is now associated with in France and in other European countries is a ballooning stomach. Pictures of overweight American children and adults are regularly used in French TV news, shows and in the print media. Every campaign against obesity in the land of gourmandise cites the latest statistics on the overweight population in the United States. "Obésité: la France sur la voie des Etats-Unis," warned Le Monde in the headline of its two-page spread on the new "epidemic" published on January 20, 2006. Even worse, continues the journalist, "in 2020 the French will resemble today's Americans" (Blanchard 22). France's current Health Minister regularly cites obesity as a major health threat, whereas as little as five years ago, Le Monde points out, the topic was not one of the Ministry's preoccupations. The press would have us believe that obesity really represents a major health threat in France, and that "Americanization," defined, among other ways, as having a sedentary lifestyle and increasing one's consumption of sugar and fat (Perez 7), is making the French gain weight.

2 The French have always indulged in vocal disdain when it comes to the subject of eating in the United States and in certain other countries. The myth of the American dinner guest asking for a glass of Coca-Cola to drink with the French delicacy foie gras simultaneously denigrates Americans and flatters the superior gastronomic culture of the French. The jokes about the hopeless lack of taste in American cuisine and the corresponding lack of appreciation of fine food are not just part of the private sphere. The comment that Jacques Chirac made at an international summit in 2005 about Britain having the worst food in the world just after Finland shows that food is at the heart of a demagogical discourse which a certain part of the French population (both on the right and on the left of the political spectrum) takes pleasure in. Even American food rations sent to disaster zones have been criticized in the French and European media. 
3 Ironically, as little as ten years ago, the American way of life was synonymous with slenderness in France. Americans were joggers or fitness freaks and non-smokers to boot. Images of President Clinton being interviewed sweating after his morning run were interpreted as another sign of an American lack of savoir vivre and were always good for an easy laugh. No one, however, accused the Americans of trying to make the French jog. By the year 2000, the laughs were being replaced by accusations that French food, eating habits and bodies were in danger of becoming "Americanized." The same rapid transformation in the image of America has been noted in England as well. As a journalist for The Observer remarked,

[t] he Americanisation of our bodies once meant importing the concept of the gym, a religious ritual of bodybuilding and aerobics among machinery and wall-to-wall mirrors; and diet gurus like Dr. Atkins and Weight Watchers who preached carbohydrate bans and calorie counting. Today, especially outside the metropolitan areas, the Americanisation of our bodies means obesity (Odone 27).

Over the last few years, an anti-obesity discourse has emerged and is now adding a new dimension to anti-Americanism in France. Obese Americans have become the media icons of the "shameful" side of life in the United States. Rolls of fat are not only taken as signs of a bad diet, they symbolize American decline, the failure of its public health policy, and its ultra-liberal economics. A new reading of Americanization is emerging in France; the changes in food culture and bodies are pushing the quarrels about the Americanization of the French language and its cinema out of the spotlight. The fact that it seems more and more inevitable that France will ultimately face the same problem with an overweight population has made the attacks more scathing and is creating an atmosphere in which finger-pointing is deflecting attention from the real problem. I will argue that this reading of obesity in America is inherently flawed because it is based on only a partial understanding of the phenomenon.

The claim that America is "exporting" obesity is a serious one, and it is difficult to grapple with. It is necessary to use historical-cultural resources which demonstrate how representations of obesity and overeating are the result of a complex interaction between food culture, medical advice, sociological studies, political discourse and marketing strategies. In my research, I have found that current attitudes towards obesity in both countries are in fact the result of ideas which may easily be traced back over one hundred years. The preoccupation with extra weight is not simply a presentday concern and there is much to be learned from taking a longer view of the question. Using recent diet histories, critical exposés of food industry practices as well as nineteenth-century advice literature, I will attempt to address the question of the breaking down of food cultures in America and France, to debunk certain myths about dieting while identifying a key difference between perceptions of the obese in both countries, and to expose how obesity is exploited in publishing and marketing. I will argue that the demagogical rhetoric on American food and obesity in France masks the much deeper responsibilities of international food conglomerates which manipulate guilt-ridden consumers and governments who fail to protect them.

Food Culture and Americanization

6 The definition of food culture given by the authors of Food Wars is as follows: "a constellation of socially produced values, attitudes, relationships, tastes, cuisines and practices exhibited through food" (Lang and Heasman 185). Food culture is likened to a set of rules that naturally regulate the consumer's relationship to food. In the case of French food culture, one of its main benefits is preserving the consumer from the 
negative effects of overeating through moderation. For example, meal times are set and respected in the majority of cases. Most Americans would have to think back to the 1970 's in order to remember a time when it was not common to snack all day. Another basic element of food culture is the ability to identify and be able to cook a few national dishes. The days when such Yankee standbys as pot roast, clam chowder or apple pie were consumed on a regular basis seem to be past us now; Americans would be more likely to cite pizza, tacos or the hamburger as the national dish. Cooking is increasingly represented and even marketed as strictly a holiday or leisure-time activity.

Many European food cultures have also become permeable to strong foreign influences, witnessing the displacement of some of their emblematic national foods. In England and Germany, for example, sales of fish and chips and wurst have been overtaken by those of curries and kebabs. But in France one gets the impression that a wealth of dishes are still enshrined in the collective national consciousness, like cassoulet, bœuf bourguignon, or blanquette de veau, to name only a few. Couscous has attained its place in French food culture, but is far from displacing other national dishes. French food culture remains one of the strongest in the Western world for a variety of reasons. Not the least of these is the respect the French have for the "terroir" (a word which, revealingly, is not translated into English but used as such in food writing) where particular foods are grown. A glance at the "Carte Gastronomique de la France" in Grimod de la Reynière's Gastronome Français (1828) shows how stable French food culture is. The same signature products and dishes lovingly drawn in each region on this map are still in place today. Fresh ingredients are available and there is knowledge of how to purchase them and use them that is in danger of disappearing in the U.S.

8 "Colas and burgers are now synonymous with America," according to the British authors of Food Wars (Lang and Heasman 190). Sadly, it is true that American food culture boils down to McDonald's, Subway and Kentucky Fried Chicken in most foreign countries. Increasingly, however, foreign critics are not the only ones who ask if American food culture is dead. The American author of The Omnivore's Dilemma, Michael Pollan, recently began an article for Time magazine with the observation that "once upon a time Americans had a culture of food" (Pollan 97). Among his tongue-incheek solutions to the lack of food culture is "Don't eat anything that your great-greatgreat grandmother wouldn't recognize as food." While his tone is certainly provocative, his message is clear - what's killing American food culture is an obsession with cheap food and convenience. In Fast Food Nation, Eric Schlosser remarks that "on any given day in the United States about one-quarter of the adult population visits a fast food restaurant" (3). A critic for the New Yorker recently complained that "we've become an eat-on-the-run, absent-mindedly feeding, cup-holder culture" (Shapin). Unfortunately, for all their research and insightful analysis, these exposés or a film like Super Size Me haven't brought about any concrete changes in the fight to preserve America's food culture.

9 What these critics all point to is the fact that American food culture was the first victim of "burgerization," or the industrialization of the food supply. I would argue that "burgerization" is what the French have in mind when they decry Americanization. In France, the "Americanization" of food is given a variety of definitions ranging from the tendency to drink colas, to overuse ketchup, to eat between meals, and to patronize fast food restaurants, McDonald's in particular. But if we look beyond the anti-American 
rhetoric on fast food and obesity and France, the basic fear here is that food culture is in danger. The French philosopher Michel Onfray, founder of the Université Populaire du Goût in Caen, Normandy, decries the "formatting" of food, and its "standardization" due to the liberal economics of the food industry. This fear is completely justifiable, and Onfray's efforts to re-establish the taste for authentic cuisine made with inexpensive local vegetables demonstrate how the fight against obesity should be lead. But what French critics of "burgerization" don't realize is that it is only half of the story of how the fabric of American food culture has come unraveled. The other half is the rise of a moralizing, medicalized diet culture in America.

Why Diet?

10 This is not the first time that France and the United States have faced an "obesity crisis." In fact, in both countries, obesity and dieting have been a preoccupation for well over one hundred years. There is a widely-held yet erroneous belief in the United States that diets do not exist in France. The "French paradox" trumpeted in the American media for many years and the recent bestseller French Women Don't Get Fat gained so many followers in the United States by using the message that the French all effortlessly maintain ideal weights. There is, however, much evidence which belies this myth: from "diet" products like Triscuits crackers which were marketed in France to fight fat and diabetes (Stearns 161) as early as the 1900's to American diet pills with amphetamines which were brought to France in the 1950's, as well as Slimfast and the recent "Montignac diet" (a rewrite of the Atkins diet).

11 In fact, the idea that perfect self-regulation exists is a powerful marketing message in the United States. The release of French Women Don't Get Fat was followed by the new books Mediterranean Women Stay Slim, Too and, the Japanese not wanting to be outdone, Japanese Women Don't Get Old or Fat. Publishers are selling Americans the image of France as a country where anything can be eaten, in moderation; it is a sort of paradise where one can go off one's diet forever. While it is not false that moderation is a pillar of French food culture, it is crucial to examine historical attitudes to fat, motivations for dieting, and the use of publishing and marketing in both countries more closely in order to understand why moderation has historically worked in France whereas Americans are confused by extremes and practically doomed to be overweight.

While at many points over the last two centuries, weight loss seems to have been a preoccupation both in France and the United States, our motivations and methods have diverged. Brillat-Savarin said in Physiologie du Goût in the early nineteenth century that the majority of women devote their entire lives to obtaining the right proportion of embonpoint - neither too much nor too little. This still holds true in today's France, where women watch their weight very carefully. The French have always emphasized beauty and strict norms of bodily aesthetics as the primary motivation for dieting. As early as 1804, the French doctor P.J. Marie de Saint-Ursin warned women in his book dedicated to Madame Bonaparte, L'Ami des Femmes, that an excess of embonpoint was deforming and dulling (327-8). In 1895, Mme de Géry, author of Leçons de Coquetterie et d'Hygiène Pratique, proclaimed that obesity was "one of the worst disabilities which may afflict women" because it robs them of their charm (Géry 6). In La Santé de la Femme (1895), Doctor E. Monin prescribed the following drastic diet for obese women to lose 15 to 17 pounds per month: 
at breakfast, 50 grams of toasted bread and one cup of black coffee; at 10:00 am, two eggs with no bread; at noon, 250 grams of rice or potato; at 5:00 pm, one cup of black coffee; at 7:00 pm, 100 grams of bread, 100 grams of lean ham and 40 grams of cheese (117, my translation).

In the nineteenth and early twentieth centuries, the United States and France shared an emphasis on the relationship between diet and overall health. In France, a concern about the relationship between overweight and sterility emerged in dietary advice, especially for men. In Secrets de Santé et de Beauté (1904), Dr. Monin claimed that the ruling class in France was threatened with extinction because of its obesity and, worse, it was paving the way for the triumph of the working class (20). Monin was also particularly concerned with the alarming number of cases of gout and diabetes amongst his wealthy male patients. In Comment on défend sa Virilité: la lutte contre l'impuissance et l'anaphrodisie chez l'homme (1901), his portrait of an obese man is scathing - a man in his forties, with an enormous stomach hanging over "what once were genitals" which have become atrophied and withered. In the United States, early diets like Graham's, Salisbury's or Fletcher's focused on treating problems with digestion. The diets one may find in French nineteenth-century hygiene treatises are every bit as draconian as American diets from the same period.

But what French and American diets have never shared is the moralizing tone and relentless association of overeating with personal ethical failure, a trait that is present in the United States. Mocking overweight people, now known as "fatism," has a long history in the United States. Worse, overweight people in America are routinely caricatured as lazy, incompetent and even suspicious. This is all the more stigmatic because in democratic, Protestant America, success in maintaining one's appearance has long been presented as a personal and moral responsibility which is accessible to everyone. Improving one's body is assimilated to doing one's civic duty (the President's Physical Fitness Award is given to schoolchildren who can do a certain number of situps, pull-ups, can sprint, etc.) or participating in a "democratic" process.

A perfect illustration of such thinking is the intense scrutiny under which the president's body and eating habits have fallen over the last century. Criticism of fat politicians mounted in the nineteenth century and reached a fever pitch during William Taft's presidency (1908-1912). Van Buren, Fillmore, Grant, Arthur, Cleveland, McKinley, Theodore Roosevelt and Taft were all routinely described as obese. Taft, however, was the only president cowed into watching his weight while in office (he weighed 340 pounds) before William Clinton. His first act after leaving office was to go on another diet. He has become a regular feature in American writing on food and the diet, emblematic of the turning point in America's bodily aesthetic from stout to slender one hundred years ago. Scholars have unearthed a large number of anecdotes, cartoons and testimonials about his food addiction. His most recent biographer states that "one cartoonist depicted a corpulent Taft sitting at a gigantic table shaped like the United States entirely covered with dishes of food" (Anderson 34). He was mocked not only by rival politicians, but also by members of his own White House staff and openly criticized by his wife. While it is now common knowledge that the White House bathtub had to be changed for him because he was too fat, the interview he gave to newspapers on his diet is not well-known. On Dec. $12^{\text {th }} 1913$, the following headline could be read in the New York Times: "Mr. Taft on Diet Loses 70 Pounds." In the article, Taft describes the diet he carried out under medical supervision in great detail: "I have dropped potatoes entirely from my bill of fare, and also bread in all forms. Pork is also 
tabooed, as well as other meats in which there is a large percentage of fat" ("Mr. Taft" 1).

16 The importance of Taft's story for our analysis is manifold. First, the fact that even a president in office could be subject to such cruel mockery is illustrative of the great contempt Americans had for the obese, contempt which started well over a century ago. No one is exempt from judgment on the basis of his or her body size and shape. This excessive climate of judgment has even lead to the constitution of groups of obese Americans who are making claims for compensation because of discrimination. Such persecution over intimate personal details is unimaginable for a public figure in France. The French people are simply not interested in knowing the weights of those in public office. Indeed, if we examine the French attitude to overweight men, the tone is much less moralizing. The Daumier caricatures of the fat bourgeois or Maupassant's railing of fat priests and overweight cuckolds remain on the level of political or social satire. It is common to forgive men for carrying more than a few extra pounds because they appreciate the finer things in life. Overweight French women may be mocked (the French cook Maïte or the French actress Sonia Dubois come to mind) and under pressure to shed their extra kilos, but they are not hounded by the press like the American actress Kirstie Alley. Alley was harassed by tabloid photographers who took pictures of her eating to accompany the weekly stories about her weight gain. The year 2005 saw an explosion in obesity-themed plays, memoirs and TV shows in the United States. In Fat Pig, a play by Neil LaBute, a man falls in love with an obese woman, but cannot face introducing her to his friends. Fat Girl is an unflinching memoir about fat and misery by Judith Moore. Fat Actress, Alley's TV show, is a send-up of her own victimization by the media. Being fat in America, with all the shame, rage and misery it engenders, is emerging as the central focus of a new body of fictional and non-fictional works.

17 Secondly, Taft's story is remarkable in its recognizable modernity for American dieters. All the elements of the current American diet culture were already present - cruel taunts, feelings of personal failure, suggestions of incompetence in his work, misguided attempts to lose weight, struggling to exercise without getting any results, coverage in the press of Taft before and after his diet, and, finally, gaining the weight back. Reading his story, one is struck by the amount of anti-fat rage which was directed at him at a moment when American food culture would change forever under the influence of dieting. Taft's predicament illustrates the trajectory of millions of Americans caught in the psychological torment of repeated weight losses and gains which undermine their self-esteem and end up contributing to their obesity. There is little awareness of the extent of the American dieting phenomenon in France, or of the role it has played in destroying American food culture. Salisbury's diet of 6 pints of hot water and 3 pounds of broiled "Salisbury steak" per day, launched in the 1870's, may seem absurd now (Schwarz 101), but its absurdity has been matched time and time again in America in countless other diets. The demoralizing and contradictory claims of over a century of diet advice has weakened our ties to an authentic way of eating.

Sensationalizing Eating, Marketing the Cure

The fact that Taft's struggle with weight was widely publicized and is still written about gives us an indication of the advanced development of what I would refer to as the "diet press" in the United States in the early twentieth century. Publishers discovered long ago that stories about spectacular eating habits or diets sell. A brief illustration of 
this is the Tanner story. Inspired by the story of Molly Fancher, a girl who supposedly lived for several years without eating, Henry Tanner undertook to fast in public under medical supervision. The "fasting challenge" that he started in 1880 could just as easily happen today. On the eleventh day of his fast, he began charging the New York crowds who gathered to see him fast 25 cents per person. The fast was extensively covered in the New York Daily Tribune as well as in other American and British newspapers. On the fortieth day of his fast, he had lost thirty-five and a half pounds. Other "hunger artists" followed suit, capitalizing on the sensationalism of voluntarily wasting away to make money. Later, others, like suffragettes, seeking the spotlight for political causes, would use fasting as part of a publicity campaign.

At the other end of the spectrum is competitive eating. As a New York Times journalist recently observed, "The mere fact that there are two books on [the subject of competitive eating] says something about food writing at the moment" (Grimes). Eat this Book and Horsemen of the Esophagus say even more about America's obsession with excessive eating behaviors, be it reckless abandon or punishing control over one's appetite and body. Americans are enthralled by feats which used to be part of country fairs, but are now also organized by an international committee and publicized on Internet sites like "Competitive Eating News." The "gurgitator" Sonya Thomas currently holds the competitive-eating record for oysters (46 dozen in 10 minutes), hard-boiled eggs ( 65 in 6 minutes 40 seconds) and toasted ravioli (4 pounds in 12 minutes). These incidents of fasting and competitive eating, and their exploitation for commercial purposes, share a strikingly similar grimness. They both suggest the extent to which a morbid fascination with deviant acts of consumption has developed in the United States.

The emphasis on deviance has created an atmosphere in which Americans are under intense moral pressure to lose weight. They are currently exposed to "in-depth" reports on obesity on an almost daily basis. A new, intense voyeurism of the expanding body that goes far beyond what Taft experienced is developing. It's not only a phenomenon limited to photos of fattening celebrities in tabloids or to sickening reality TV shows; "respectable" publications all have regular articles on obesity. The 16-page feature on obesity from National Geographic Magazine ("Why are Americans so Fat?" August, 2004) is a perfect illustration. It includes a profile of a woman about to undergo gastric bypass surgery (with before and after pictures), glossy charts on the evolution of the American diet, a map of world obesity rates, the inevitable Body Mass Index chart, and an MRI scan of an obese woman and a woman with a normal body weight. The journalist interviews a number of leading scientists and nutritionists who insist that the solution is to simply lower calorie intake. While that message seems obvious, the article, like so many others, is long on questions and short on answers. Similarly, in an endless list of publications, authors sensationalize the problem of excess weight by alarming readers with the latest statistics and a long list of adverse health effects, but ultimately entertain and comfort them with stories about celebrity chefs, the search for the most exotic dish, and survivors of multiple surgeries whose lives have changed forever.

21 Numerous diet scholars have evoked this atmosphere of extremes in the American diet. One idea comes back again and again in their work - the act of consuming food has become charged with an unbearable tension because the consumer is trapped by mixed messages. According to Michael Pollan, the “'American paradox' is notably unhealthy 
people obsessed with the idea of eating healthily" (Pollan 97). What Peter Stearns calls "ironic" (67) or the "great anomaly" (127) is the integration of dieting into consumerism. One of the central messages of the National Geographic article is another quandary: “The real question [...] isn't why so many of us are getting fat, but why, in our food-rich environment, is anyone thin at all?" (Newman 60). The most compelling analysis, however, is certainly Hillel Schwarz's. Twenty years ago, he laid the blame for overweight squarely on the food industry, claiming:

Capitalists have as vital a stake in the failures of dieters as in the promotion of

dieting. It is through the constant frustration of desire that Late Capitalism can

prompt ever higher levels of consumption (328).

His position was echoed in Richard Klein's work. Klein stated in his 1994 article "Big Country" (New Republic): "My hypothesis is this: if marketers can create guilt in a population saturated with fat, they can use obesity to sell both health and unhealth" (Klein 28). Is it any wonder, as the New York Times pointed out in a recent article on the link between obesity and global warming, that the bad news about obesity makes overweight people want to eat more? (Kolata).

Though they may highlight different aspects of the phenomenon in their work, critics agree that obesity in the United States is at least partially the result of the aggressive marketing techniques used by the international food conglomerates. The consumer is bombarded with mixed messages. There are thousands of examples of advertising for "healthy," "no-fat" food loaded with sugar in the United States. Television advertising directed at children has been measured and denounced, but perhaps even worse is the way marketers have infiltrated schools and children's sports teams through "partnerships" like Walker's crisps free-books-for-schools initiative, or Cadbury's vouchers for sports equipment programs in England, or free textbook covers with advertisements for Gatorade, Hershey, etc. in the U.S. School districts across the United States have signed lucrative contracts with major beverage companies. This heightens the confusion of young people who are increasingly unable to make healthy food choices because the institutions they are supposed to trust make a profit from "brand awareness" and "brand loyalty" campaigns directed at them. This type of intervention primes them to be steered through the supermarket aisles as adults from "off-diet" to "on-diet" items processed by the major brands. New packaging of hitherto "off-diet" items like Oreo cookies in "100-calorie" bags is the latest promotional stunt which allows the food companies to charge more money for their product while sending the message that they support the consumer's diet initiative.

Until recently, the French had been spared the news items on obesity to which Americans are exposed. Now, not a day goes by in France without another reminder of the fact that obesity is gaining ground here, as in the United States. The French press is undeniably creating more anxiety in the population. The media treatment of reports on the latest obesity figures in France, released on September the $19^{\text {th }}, 2006$, continued in the same vein, but with a new insistence on reporting the difference between the North of France, with higher rates of obesity, and the South. The obese are being counted, counseled and informed via public health campaigns. The notion of the "indice de masse corporelle" (body mass index) is catching on. There are an increasing number of television shows about overeating, anorexia, plastic surgery and diets. Correspondingly, there have never been so many ads for anti-cellulite gels and diet products. Recently, one Parisian woman died and fifteen others were hospitalized while on a medically supervised diet including thyroid pills which were prepared improperly 
(Olivier). As we have seen, overburdening eaters with guilt has had dire consequences in the United States, and this should be kept in mind by France's public health officials.

Similarly, France had also remained relatively free of health-claim food marketing. Because its food culture is based on the principle of a balanced diet, there simply had not been major opportunities for foods with vitamin supplements or other healthbased claims to gain market share. Over the last few years, however, health claims have blossomed on French food packaging as well, promoting calcium or Omega 3 fatty acids. But health-claim marketing was taken significantly further when Unilever and the health insurer MAAF, followed by Danone and the insurer AGF, were allowed to launch marketing initiatives based on the medical claim that sterols contained in their products help reduce bad cholesterol. In the case of Danone, AGF reimburses its subscribers for their purchases of Danacol (for 2 containers or one bottle of the product for 92 days within an annual limit of 92 Euros). While Unilever was taken to court by a consumer's rights organization and Danone's campaign was denounced as manipulative (Smée), the promotions went on. Unilever is undoubtedly hoping to duplicate the results it obtained using the same promotional method in Holland in 2005 - a 25\% increase in sales (Gallois and Malingre). New guidelines for health-claim marketing in the European Union are due to be set. Will they protect the consumer from more confusing messages or simply stand back and let business go on as usual as in the United States?

Conclusion

26 Food is less and less of a simple pleasure in the United States. Food advice culture, which has constantly grown stronger since the end of the nineteenth century, is used by marketers to manipulate the consumer with conflicting messages about weight loss and conformity to norms. Preparing food at home and eating it has become fraught with difficulties, and not just because Americans drive further to and from their jobs and spend more time working. Convenience and money are not the only issues. Reading the packaging on food items has become more complicated and anguishing than choosing from the menu at Wendy's. Paradoxically, guilt and fear about eating lead consumers to make even unhealthier choices, and to eat alone for fear of being judged.

Nothing, from lawsuits to exposés or the work done by scholars of the diet and body image, has stood in the way of the relentless expansion of the processed food industry in the United States, and, now, in Europe and developing countries. The "burgerization" of part of the world's food supply cannot be reversed, but it can be contained through more strict regulations. Governments and critics, however, must properly identify the adversaries. The globalization of food is no longer American. A journalist for Les Echos recently wrote an article entitled "La mondialisation se poursuit, mais l'Amérique ne la mène plus" (Vittori 16). His thesis is that other forces are now leading globalization, making all the opposition to Americanization in France a moot point. As Philippe Roger pointed out in his conclusion to L'ennemi américain, it makes no sense to fight fast food on American criteria of nutrition and public health, when better arguments like taste and conviviality would be more pertinent and persuasive for the French (574). Michel Onfray's recent call to reduce what he refers to as a "fracture alimentaire" between social classes in France does not mention the United States. It simply outlines the most efficient way for the French to fight obesity by teaching people how to use the affordable ingredients at their disposal. Finally, France already has all the tools it needs to defeat obesity: a strong food culture which 
emphasizes the positive aspects of pleasure in eating, a better public health system, fewer television ads, less health-claim marketing, and no marketing initiatives in schools. It shouldn't need to conjure up anti-Americanism to get the job done.

\section{BIBLIOGRAPHY}

WORKS CITED

Anderson, Judith. W.H. Taft, an Intimate History. New York: WW Norton and Co., 1981.

Banting, William. Letter on Corpulence. New York: Mohun, Ebbs and Hough, 1864.

Blanchard, Sandrine. “Obésité: la France sur la voie des Etats-Unis”. Le Monde 20 jan. 2006: 22.

Bumgarner, John R. The Health of Presidents. Jefferson: McFarland and Co., 1994.

Fantasia, Rick. "Restaurants rapides pour 'sociétés sans classes." Le Monde Diplomatique (mai 2000): 6-7.

http://www.monde-diplomatique.fr/2000/05/FANTASIA/13728

Consulted on 16 Feb. 2007.

Gallois, Dominique and Malingre, Virginie. "AGF et Danone soignent leurs clients en remboursant des yaourts." Le Monde 5 avril 2006. http://www.lemonde.fr/web/article/ 0,1-0@2-3234,36-757782@51-725645,0.html Consulted on 17 Apr. 2007.

Géry, Blanche. Leçons de coquetterie et d'hygiène pratique. Paris: Thirion, 1885. Grimes, William. “Haute Extremes: Today's Food Writing.” New York Times 31 May 2006. http://www.iht.com/articles/2006/05/18/features/grimes.php Consulted on 17 April 2007. Grimod de la Reynière, A.B.L. Gastronome Français. Paris: Imprimerie de H. Balzac, 1828. Klein, Richard. "Big Country." The New Republic 13 Aug. 1994: 28-38.

Kolata, Gina. "For a World of Woes, We Blame Cookie Monsters." New York Times 29 Oct. 2006.

http://www.nytimes.com/2006/10/29/weekinreview/29kolata.html? ex=1176955200\&en=88232a001ab8699b\&ei=5070 Consulted 17 Apr. 2007.

Lang, Tim and Michael Heasman. Food Wars: The Global Battle for Mouths, Minds and Markets. London: Earthscan, 2004.

Lévy, Bernard-Henri. American Vertigo. Paris: Grasset, 2006.

Marie de Saint-Ursin, P.J. L'Ami des Femmes. Paris: Barba, 1804.

Monin, E. Comment on defend sa virilité. Paris: L’Edition Médicale, 1901.

---. Secrets de santé et de beauté. Paris: F. Tedesco, 1904.

---. La Santé de la Femme. Paris: Doin, 1895. 
“Mr. Taft on Diet Loses 70 Pounds." New York Times 12 Dec. 1913: 1. http://www.apneos.com/ nyt1913.html. Consulted 16 Feb. 2007.

Newman, Cathy. “Why are Americans So Fat?”. National Geographic Aug. 2004: 46-61.

Odone, Cristina. “Cristina Odone's Diary”. The Observer 4 May 2003: 27.

Olivier, Vincent. “Maigrir, mais à quel prix?” L'Express 2 mai 2006. http://www.lexpress.fr/ info/quotidien/rss.asp?id=3607 Consulted 17 Apr. 2007.

Onfray, Michel. “Texte” written for the Université Populaire du Goût,

http://perso.orange.fr/michel.onfray/universitepopulairedugout.htm\#texte Consulted 16 Feb. 2007.

Perez, Martine. “Sciences et Médecine.” Le Figaro 14 nov. 2002: 7.

Pollan, Michael. “Six Rules for Eating Wisely.” Time vol. 167, no. 2412 June 2006: 97.

Roger, Philippe. L'ennemi américain. Paris: Editions du Seuil, 2002.

Schlosser, Eric. Fast Food Nation. New York: Houghton Mifflin, 2001.

Schwarz, Hillel. Never Satisfied: A Cultural History of Diets, Fantasms and Fat. New York: The Free Press, 1986.

Shapin, Steven. "Eat and Run." The New Yorker 26 Jan. 2006. http://www.newyorker.com/ archive/2006/01/16/060116crbo_books Consulted 17 Apr. 2007.

Smée, "L'UFC-Que Choisir perd contre la MAAF." Novethic.fr 14 juin 2006.

http://www.novethic.fr/novethic/site/article/index.jsp?id=101439\&titre=L'UFC-

Que\%20Choisir\%20perd\%20contre\%20la\%20Maaf Consulted 17 Apr. 2007.

Stearns, Peter. Fat History, Bodies and Beauty in the Modern West. New York: New York University Press, 1997.

Vittori, Jean-Marc. "La mondialisation se poursuit mais les Etats-Unis ne la mènent plus." Les Echos 15 juin $2006: 16$.

INDEX

Keywords: obesity, Americanization, diet, food culture, fat, fasting, competitive eating, food marketing, fast food, globalization.

\section{AUTHOR}

LAURA KNOWLTON - LE ROUX

Laura Knowlton - Le Roux, Université de Haute-Bretagne, Rennes 2 